\title{
On the Self Management in MET Development
}

\author{
Wang Ji-chang \\ Human Resource Management, Qingdao Ocean Shipping Mariners College, Qingdao 266071, China
}

\begin{abstract}
Maritime English teaching has placed higher requirements on the part of the teachers. In combination with the requirements and the characteristics of maritime English teaching, this article puts forth new viewpoints for the self management of maritime English teachers and provides evidence in the aspects of theory and practice.
\end{abstract}

Key words: Maritime English teaching, self management, teaching effects, teacher development.

\section{Introduction}

Maritime English teaching has been practiced and shaped in the process and new concepts of teaching reform have been appearing. Against this background, maritime English teachers need more than ever before keep calm in the chaos, because no matter how teaching is going on and how reform is proceeding, the guiding position of teachers still takes the lead and will continue to play its irreplaceable role. As the most important component in the process of maritime English teaching, teachers should put themselves in the macro environment of political, economic and social development, make studies in educational and teaching theories, make efforts in fundamental and detail management and continue to improve their ability in teaching and scientific researches.

\section{The Concept of Self Management}

Sociologists drew conclusion from experiments that, among all the tasks of the teachers, nothing is of greater importance than management skills. The research results of psychologists show that, among all the necessary qualifications of teachers, the ability of management ranks number three, which is higher than the seventh of knowledge ability. Hence, the management ability of teachers plays a leading role in

Corresponding author: Wang Ji-chang, engineer, senior human resource manager, research fields: human resource management, teaching resource management, economic management. education and teaching.

The understanding of teacher management can roughly be categorized into macro and micro managements. Macro teacher management is external and refers to the organization and management systems in the process of language teaching. It includes three aspects: (i) The foreign language teaching theories established in accordance with linguistics, pedagogics and management theories and the relevant teaching management models; (ii) The organizing structure, culture, staff management and construction; (iii) English teaching process, course establishment theories, design and development of teaching syllabuses, teaching evaluation and testing means [2]. The micro maritime English teacher management refers to the fact that in the integrated process of teaching in which the teachers conduct self management on their teaching and teaching specific items and processes. It includes: (i) Learning, understanding and implementing the relevant policies and spirit and combining them into the routine teaching and studies; (ii) Formulating personal career development plans and implementing them with steps and measures; (iii) Taking measures to improve their personal language abilities; (iv) Learning, studying and practicing various teaching theories and methods and putting them into their personal teaching; (v) Learning professional maritime knowledge to conduct organic combination between language skills and professional abilities; (vi) Maintaining individualized 
integrated development.

The self management of maritime English teachers belongs to micro infrastructural management and is the sure way for maritime English teachers to proceed from teachers training, teacher education to career development.

The development trend of modern college management is turning from externalization to internalization and the root of which is the teachers themselves. The problem for solution in management is to train the self management abilities of the teachers. Only by achieving the self management of the teachers can the goal of the college management be realized. The self management of college teachers is the process in which the teachers actively put forth the goal for efforts and conduct initiative and conscious implementation, supervision, encouragement and control to reach the goal. With the development of the times, the center of teacher management is moving towards the direction of self management. People realize that in order to make the best use of the value of the teachers, explore the potential of the teachers, develop their personalities and improve the effectiveness of educational management, it is necessary to make the teachers positively achieve their self management and enhance their active and overall development.

The purpose for the self management of maritime English teachers is to utmost release the personal abilities, do the correct things and do things correctly, focus on the result and cerate values for achieving the goal of education and teaching.

Looking back towards the status quo of English teachers' self management in maritime higher institutions, it is easy to reach the conclusion that, it is still non-instinct and chaotic.

(1) Short of understanding of educational policies, with a reflection of missing the orientation of teaching. Most teachers only care about the tasks of the present terms, without the integrated understanding among the terms, grades, teachers and subjects, resulting in the discontinuity and isolation;

(2) Short of studies on teaching methodologies, showing a status quo maintained and blindness in face of various teaching contents. Short of clear understanding, evaluation and application on the methodology frequently used and sometimes even follow the fashion of inapplicable methods, which runs the other way round from the teaching objective;

(3) Most of the maritime English teachers are bachelors or masters graduating from general English majors and are in need of improving their integrated language abilities to cope with the complicated and changing teaching materials and teaching requirements. In some maritime institutions, the navigation teachers are taking the task of maritime English teaching and they should improve their language abilities to satisfy the need of the students' language learning;

(4) Maritime English teachers need to improve special knowledge in navigation in that maritime English is the coalition of navigation and English language, where navigation teachers improve their language skills and English teachers improve their navigation knowledge, complementing each other. Both the Manila amendments to STCW Convention and the 10th Decree of the Ministry of Transport have put forth clear requirements that the top result of maritime English teaching is for the students to have command of navigation knowledge through their English language ability.

Therefore, maritime English teachers should carry out self management to play a better role in maritime English teaching.

\section{Management of Teaching Policies}

The policies that maritime English teachers should make studies on include the political, administrative and teaching requirements and regulations of the government and institution. English teachers often neglect the learning of the policies and focus on the development of themselves and improvement of 
teaching abilities, however, one of the results is the loss of orientation of personal development. In China, no matter what you are engaged in, whenever you want to gain further development, you need to learn and study the policies. Policies are orientations and detailed learning and studying will often provide guidance on the development of English teachers so that they will gain the steps along the correct lanes and follow the requirements from above.

Learn about the 13th five-year plan and you will find its characteristics, as greater emphasis on fundamental development, elimination of eagerness for quick success and benefits, enforcement in sustainable development and avocation for talents strategy. The enlightenment that we can draw from the 13th five-year plan is: (i) Take hold of the self infrastructural development of teaching, including the improvement of language and teaching abilities, career and professional development; (ii) Render orderly combination of academic education, professional titles, teaching and research as the orientation of development; (iii) The nation, institution and teachers all have the need for development; (iv) Treat the teachers and students as talents for cultivation and improve them to a higher level which benefits the dual development of teaching and learning.

Learn about the 13th five-year plan and teachers will know the general direction for college development, present and future expectations, teaching resource development and requirements for improving teaching levels, etc. Therefore, teachers are able to make three-year personal development plan, five-year professional title plan and life-long study plans, etc.

Learning of the emended version of STCW Convention will bring the maritime English teachers to a better understanding of the latest international requirements so that their teaching will suit the new situations and reduce the blindness and reflect upon their students, (i) Satisfactory expression in oral
English; (ii) Effective communication; (iii) Application of working language; (iv) Correct use of professional terminologies.

Learning of "Management regulations for seafarers' training, PRC" will clarify the maritime English teachers with the "requirements for the training of oceangoing seafarers" for the satisfaction of the requirements for maritime English teaching staff to improve the teaching and training effect.

The learning and understanding of College English Teaching Syllabuses will take maritime English teachers to gradually establish the senses of language, learning and education, and bear in mind the history of teaching syllabus development and the formulation of education and teaching ideologies. A famous Chinese linguist says that, foreign language teaching is a science from the aspects of teaching methods, textbooks, syllabuses and plans, because it has its own principles. For example, the 1962 edition of "English Teaching Syllabus" made by the Ministry of Education for higher industrial institutions is one guided by the grammar-translation teaching methodology. The one that came into force in 1985 is one guided by communicative English teaching syllabus, with the contents concerning the teaching objectives, subjective, requirements, arrangement, suggestions in the process of teaching and means of testing. The syllabus also contains vocabulary required, grammar structure tables, functional and notional categories and language skills. The "Course Teaching Requirements for College English" issued by the Ministry of Education in 2004 is clearly one for task-based language teaching syllabus and one blended with various teaching methodologies, which states that, college English is a teaching system guided by foreign language teaching theories, with its contents including knowledge and application of English language, learning strategies and cross-cultural communication and integrated with multi teaching models and means. This syllabus places stresses on the importance of foreign language 
teaching theories and clarifies that the language teaching and acquisition have its innate principles. Therefore, teachers should be familiar with the relevant theories directly related to foreign language teaching, such as linguistics, second language acquisition, learning strategies and constructivist theories, etc., and consciously use theories to guide their teaching practice, which will better suit the language teaching principles in achieving the satisfactory results. The observation of the development history of teaching syllabuses shows that, the evolution of syllabuses is based on teaching theories, reflects the orientation of social and economic development and puts forth clear requirements for periodic English teaching. The learning and understanding of teaching syllabuses will assist the teachers in teaching research and practice, produce guiding influence for their teaching so that the language teaching will better meet the requirements of the society.

\section{Management of Personal Level}

Presently, China does not have a standard for English teachers' language ability which results in the inadequacy of English teachers in the basic language skills of listening, speaking, reading and writing. For this, some experts express that, for improving the level of English teaching, the key lies in improving the language level of the teachers. When teachers are weak in language, how can they teach their students? Today, even professors in famous universities are weak in English. No matter what methods they use, how can they teach good students? The teaching staff remains a problem, the introduction of methodologies will not solve the problem.

Today's professional title assessment lacks clear and concrete professional standard and scientific evaluation methods and is short of systematic teaching training target and evaluation system. One of the aims for teacher development in the "Outline of the national medium and long term educational reform and development plan" is, establishing a highly qualified teaching staff, to strictly control the teaching resources, improve the qualifications of teachers, strive to create a professional teaching staff characterized in high moral level, exquisite in teaching, reasonable in structure and full of energy and passion. Therefore, it is necessary to make the professional criteria for English teachers, provide indexes for teacher development to make it scientific and systematic, establish unified, clarified and objective professional standard and scientific evaluation method, which helps the overall improvement of English teaching resources and long-term development of teachers. English teachers are totally able to organize groups for the study and establishment of relevant regulations and standards to specify the English teaching staff and make it proceed along the road of prosperous development.

In accordance with the understanding of the author, a qualified English teacher should have the following characteristics.

(1) Real and corresponding educational records of higher institutions, as bachelors, maters or doctors;

(2) High level of English and Chinese listening, speaking, reading, writing and translation and the effective use of them;

(3) Systematic knowledge of western culture and free application of it in teaching;

(4) Systematic language knowledge and solid teaching ability;

(5) Capability in scientific research;

(6) Command of modern educational technology;

(7) Pleasant personality and outgoing personality;

(8) Rational evaluation of students, classes, college development and improvement.

The questionnaire survey conducted to 920 English teachers from 49 higher institutions shows that, 78\% of the teachers believe that a good English teacher should have high level of basic knowledge in English language, which demonstrates a clear demand of language knowledge and ability by the teachers and 
realization that the language abilities of the teachers directly influence the effects of teaching; $58 \%$ of the teachers wish to have the opportunity for professional refreshment and for the ways of improvement, $47 \%$ of them choose "going abroad to native-speaking countries" and $27 \%$ wish to exercise on occupation development; for the contents of development, 29\% choose for linguistic theories and $20 \%$ choose basic language skills [3].

It is profitable to put teacher development in the sustainable development of the institution and not only the institution should have plans for teacher development but also teachers themselves should make plans for personal development based on their own backgrounds. The most essential requirement for teacher development is the continual improvement of the language levels. In addition to the institution actions, that is, the institutions arrange for the teacher improvement either home or abroad, teachers should also make short- and long-term refreshment plans based on their own orientations and resources. In fact, to a great extent, the English teacher development relies upon their self development. The author holds that the improvement of English teachers is based on four elements, awareness, attitude, skill and knowledge, where the first is decisive and functions as inspiring and controlling the other three. When you have the inspiration for development, you will have the active attitude, which triggers the accumulation of knowledge and improvement of ability.

The improvement of the English teachers' language ability includes: (i) Self improvement, setting up learning plans and book list for the reading of the relevant professional books; establishing learning diaries, recording the contents, gaining and reflections. Jarvis believes that keeping the learning diaries is a good means for self reflections, which provide an opportunity and space for teachers to conduct reviews on their learning and improvement [4]; setting up learning portfolio, as Bastidas believes, a learning portfolio is selected of choice and representing the teachers' long-term reflections and the file record of the teaching concepts, self development and achievement gained in the process of self evaluation [5]. (ii) Cooperative development, the form of teachers' learning group is seldom seen in the process of teacher development except for scientific research projects and what is more often seen is that of individual efforts. In fact, it is one of the necessary qualifications of the teachers to attain the teacher development in groups. Underhill thinks that, in the environment of groups, the individual is more readily aware of the self effect and is inclined to become the better in the groups [6]. The activities as attending classes, observations and discussions, etc., will broaden the views of the teachers for objective demonstration and reflection of the hidden problems. (iii) Improvement via internet. The development of science and technology makes the internet indispensible and Barnard believes, the platform of internet for teachers' communication and idea exchange makes teachers' e-learning possible [7], while internet has become a resource available to everybody. (iv) Improvement in scientific research. To be engaged in scientific research is one of the basic requirements for teachers and in the process, teachers will often find that the low level of language knowledge hinders them from acquiring more knowledge and information. This requires teachers to reconsider their language abilities and steadfastly improve their language ability.

Actually, where English have the wish for improvement, there are many ways ready for choice and their enthusiasm in applying for higher academic titles can be transferred to the improvement of language abilities.

\section{Management of Teaching Methods}

Using applicable teaching methods is one of the requirements for maritime English teachers. On account of its professional characteristics, requirements for certification, educational 
backgrounds and status quo of the students, maritime English teaching puts on higher requirements for teaching methods. In the formation of this paper, in combination with the studies in the past, the author conducted summary and sorting of the existing teaching methods and found: (i) All the teaching methods come from the west and have their own theoretical basis and historical backgrounds; (ii) There is no one method ready that can be used directing to the contents of maritime English teaching; (iii) Maritime English teaching methods leave a large space for studies, as its professional requirements, language features, theoretical basis and event the localization of western English teaching methods, etc., will all provide a good basis for the studies and establishment of maritime English teaching methods.

Last century is one in which English teaching methods gained the greatest achievements. In the beginning, the direct method which was based on the language acquisition theories of German foreign language educator B. W. Vietor became mature after many years' practice and modification. It lays stresses on imitation and advocates to learn a foreign language through the learning of speaking and to form the language habits through listening, imitation and practice. The situational method came into being in the 30th of last century. Its theories are structuralism of Bloomfield and behaviorism of Skinner. This method believes speaking is the basis of a language and structure is the core for training the speaking ability. The learner practices the language structures in the set situations and forms the speaking habits of the target language. The popular textbooks "New Concept English", "Follow me", and "American English Album" were typically designed for situational teaching method. The audio-lingual method was born in the United States after the breakout of WW2 and the advocator was C. C. Fres. He put forth the theory of oral English as the core and structure as the center and textbooks were expressed by the oral form. He placed stresses on imitation and memorization of fixed phrases. The design of the textbook "English 900" popular in the 80 's clearly brought the features of audio-lingual method. The audio-visual method was born in France in the 50's and was one suiting the fresh courses for adults in short terms. It was first raised by $\mathrm{P}$. Guberina, who proposed to use the electric teaching equipment as slides and films, etc. to organize the teaching of listening and speaking to combine the sense of listening and that of the vision. The audio-visual method carried forward the advantages of the direct method and audio-lingual method in that it extensively uses the modern teaching techniques and equipment of sound, light and electricity to combine closely the language and image to enhance the natural and firm command of a foreign language. The cognitive method was put forth by the psychologist J. B. Carroll in the 60 's, to use the learning of the cognitive symbol to replace the theory of stimulus-reaction. The cognitive method is opposed to the theory that language is a structure and is opposed to the repeated and mechanical operation and practice in the process of teaching. It advocates that language learning is a creative activity subject to rules and the acquisition of a language is the command of the rules instead of forming habits. It lays stress on the use of understanding in the process of teaching to make language teaching situational and communicative. The task-based method came into existence by the end of the 80 's and is the product of "process syllabuses" in foreign language teaching field. Its classroom teaching procedure is: the teacher giving the tasks to the students and students, under the guidance of the teacher, collecting information, designing the plan and carrying out the implementation, and, finally, teacher and students cooperating to complete the evaluation. It lays stresses on learning by doing and doing by learning, resulting in students' natural acquisition of the language through participation in the activities and teacher-student cooperation in completing the language teaching tasks. The task-based method 
reflects the tendency of turning from teaching method to learning method, that from teacher-centeredness to student-centeredness and that from emphasis on language to language acquisition. In the early years of the 70's, the EEC member countries reformed the foreign language teaching by making the unified teaching syllabuses and designed the unified textbooks and testing models. After three years' efforts, the "entrance stage" syllabuses of the leading languages of Europe and the "notional syllabus" of Wilkins took shape, which mark the birth of communicative method. Its theoretical basis is the communicative ability theories of Hymes and the functional language theories of Halliday. The communicative method emphasizes the design of the learning process, students' participation and teacher-student interaction and added by the interest of language learning, autonomy, creativity and cooperativeness of students. The grammar-translation method that was popular for centuries was one for the teaching of Latin in Europe in the Middle Ages. The purpose of learning a foreign language for the people at that time was reading foreign language materials and literature. German linguist Heinrich Ollendorff summed up the practical experience in using grammar-translation method and, under the influence of mechanical linguistics and psychology, he provided theoretical explanation on grammar-translation method so that it became a scientific system for foreign language teaching method. This method trains the reading ability of the students and puts emphasis on the training of translation and convey of grammatical knowledge.

Observing and studying maritime English teaching, you will find its characteristics: (i) Teaching of vocabulary, concerning a series of special English words, phases and usages, rare terminologies and repeated naming; (ii) Teaching of structures, involving the special structures of maritime English, rigorous, obscure and complicated; (iii) Teaching of principles, combining language with professional principles, special in professionalism and logic; (iv) Teaching of discourses, demonstrating the fixed, jumbled and strange styles; (v) Teaching of grammar, impersonal sentence patterns, long sentences, passive voice and even anti-grammatical sentences; (vi) Teaching of examination, maritime English teaching is subject to the certification examinations with clear backwash effect.

Based on the above characteristics of maritime English teaching, teachers should, in different stages and directing against different teaching materials, adopt various teaching methods to reach various teaching objectives and put the whole teaching process in a logical and rational spiral going up manner. It is then profitable to divide the whole process of maritime English teaching into three stages: (i) Initial stage (corresponding to word level), it is necessary to enforce the teaching of reading in accordance with the learning principles and the fact that the students are having the initial contact with maritime English, use low speed, emphasize the students' cognition with the language form, enlarge their vocabulary and improve their recognition ability. This stage suits the use of direct and audio-video methods to establish their learning interest, improve their learning ability, set up their autonomous learning ability, use multimedia teaching means to present new teaching contents, enhance the students to naturally and firmly establish the link between the names and actual materials and have command of the working principles; (ii) Intermediate stage (corresponding to sentence level), enforce the training of listening and speaking on basis of vocabulary and reading, emphasize the repetition of language materials, which benefits the command and use of the language contents. The audio-video and task-based methods suit the stage, which strengthen the sentence making ability of full sentences, improve the listening and speaking and cooperative learning, set up the learning confidence and establish the model of active learning; (iii) Advanced stage (corresponding to discourse 
level), provide large amount of reading materials, improve the teaching speed, enforce the learning and practice of imitated writing and regulate the language form. Grammar-translation method suits the stage, in which, via the imitation and output to accelerate the research-based learning to reach the goal of learning maritime knowledge through language. With the coming into force of the certificate examination syllabus of the MSA, maritime English teachers should make studies on the testing principles and method to improve the pass rate of the certification examinations.

\section{Management of the Teaching Process}

\subsection{Management Prior to Teaching}

The management prior to teaching refers to teaching preparation, which is not only the writing of lesson plans, but also including the preparation of syllabuses, teaching materials, teaching methods, time allocation, students and teachers themselves, and the evaluation and adjustment of the teaching preparation activities.

(1) Preparation of the syllabus. The teaching syllabus is the guiding document, the theoretical basis for all the teaching activities, the principle in evaluating the students and the criterion for evaluating the teachers' teaching quality. It is a scientific system, provides the nature, task, contents and requirements of teaching and guidance for the application of the syllabus in the process of teaching. It regulates the scope of knowledge, skill and evaluation in the process of teaching. Through the learning and studying of the syllabus, teachers are able to organize the teaching contents into an integrity based on their own understanding and within this scope, teachers can make further studies on teaching contents, methods, styles and evaluation and implementing the presentation, so that the teaching process will be rational and reasonable in forming a perfect closed loop.

(2) Preparation of the students. Students are the subject of teaching and teachers should respect the difference of the students and place focus on the development of the individuality, because all the teaching activities should center round the educational service for the students. Teachers should have overall understanding of the students, including their knowledge, skill, morals, learning attitude, methods, interest, individual personalities and even psychological characteristics, etc., "fully understand the students, establish friendly and harmonious relations with the students, so that the results reflect the expectations of the teachers and better accepted by the students" [8]. The channels for understanding the students include: (i) Know them by the students' files; (ii) Know them by face-to-face talks; (iii) Know them in and out of the classroom; (iv) Know them through the former teachers and classmates; (v) Know them via investigation and consultancy; (vi) Know them through their parents; (vii) Know them via classroom questioning and testing, etc. The understanding of the students makes the teaching better satisfy the needs of the students and makes the learning subject become self conscious, responsible and self controlling students.

(3) Preparation of the teaching materials. Teachers should have clear understanding on the teaching tasks and objectives, the key and difficult points, have the extensive teaching materials, adequate understanding of the materials and use appropriate methods, adopt reasonable steps and transfer the teaching contents to the students in good order, give full play to the teaching materials and play the correct role in the process of teaching.

(4) Preparation of the teachers themselves. The teachers' understanding of themselves includes: (i) Full preparation for the new teaching tasks; (ii) Full confidence in the new teaching tasks; (iii) Full expectations for the new teaching tasks; (iv) Becoming the leadership in the teaching environment through the implementation of teaching, the participant, accelerator, organizer and modeler of 
learning methods.

\subsection{Management after Teaching}

The management after teaching refers to the teaching reflection by the teachers. The completion of a classroom teaching does not mean the completion of teaching, but the beginning of a new round teaching and the start point of teacher development and the reflection now is timely, active and effective. Actually, the accumulation of teacher reflection is not only the mark of teacher development but also an important process for teachers engaged in scientific research. Teaching reflection is "a means for teacher and teaching resource progress, in which, teachers reflect their teaching experience to improve their understanding of teaching and quality of teaching with criticism. The purpose of reflective teaching aims at cultivating teachers' innovative, analytical and objective thinking of the teaching process and is a channel for reforming the classroom teaching practice" [9].

"Learning" says that, learn and know your inadequacy; teach and know your difficulty. Inadequacy will take you to reflection and difficulty will bring forth enforcement. Hence the mutual improvement of teaching and learning.

Confucius said, you will get confused by learning without thinking and wasted by thinking without learning.

The "English Course Standards" of the Ministry of Education suggests that teachers should conduct reflections on their teaching activity.

In accordance with the theories of Bartlett [10], the author believes that, the process of teaching reflection is a loop composed of a series of activities, including observation, recording, analysis, query and control. The teaching reflection of English teachers is firstly observation. In this process, the teacher gets out of the ego and conducts observation of his teaching behavior and the learning activities of the students from the objective angle. The second step is recording. Writing the teaching diary is the dialogues with the teacher himself and provides the space for his reflection, the description and feedback of the teaching process. Writing the teaching diary, which is a natural and familiar style for teachers, brings the teachers to the benign process of self recognition, reflection and perfection [11]. Blookfield said, "the teaching diary is the regular record of the life activities of teachers. It consciously and vividly describes the teacher himself. It is not only a list of life activities, but also gives more hypotheses for the understanding of himself via concentrating on the matters" [12]. Thirdly, finding out the problems through analysis. Educational experts have formulated the detailed question lists, including "What is my teaching viewpoint? How do these points influence my teaching? What kind of a teacher am I? What are my viewpoints towards teaching and learning? What kind of learning style and strategy do my students like? How do I convey the teaching objectives to my students? What teaching methods do I usually explore? How are they effective?" etc., to conduct analysis on his teaching process and contents via these questions. The fourth is to raise queries. The teachers, based on their teaching practice, make a series of checklists to render comparisons of the teaching guidelines, strategies and methods, such as, how is the students' classroom participation? What merits should be kept and what shortcomings should be overcome? To find out the inappropriateness and disparities between their teaching concepts and actions. The final step is control, in which teachers take measures for the improvement of teaching. This can be a small scale teaching reform and experiment conducted within the scope of classroom, which can be performed towards certain problems, with designing action plans, making improvement schemes, testifying the feasibility and effectiveness in teaching practice and finally writing out the action research report. By this process, the teachers not only improve their ability in discovering and solving the problems, but also the ability in 
scientific research.

The characteristics of the management after teaching are: it stems from the understanding, summary and distillation of the teaching practice of the teachers and the problems found are often those that need the solutions and close to the development expectations of the teachers, which benefits the maintaining of the professional development interest and also the growth of the teachers. Teachers are not only engaged in teaching practice but also conduct scientific research on the basis. The mixture of the two favors the improvement of the integrated abilities and the personal development. In the long run, teachers can even establish their characteristic teaching theories. The whole career of teaching goes up in a spiral manner, accompanied by the teachers' systematic observation, objective analysis, hard thinking and rational choice. It is also a process of creation and innovation, where teachers subtly combine the logical critical and innovative thinking with teaching abilities and flexibly use them in the steps of teaching to produce an effect exceeding the traditional and experienced practices, that is, supernormal, innovative and reflective teaching effect. "It effectively enhances the foreign language teaching and learning theories to never readily provide the teaching methods corresponding to a certain teaching style or learners. These theories will influence the potential concepts in teachers' brain on language learning and help perfect the professional teaching behavior" [13].

\section{Management of Learning Navigational Knowledge}

Maritime English teachers should systematically study navigational knowledge to make their teaching express the characteristics of "acquiring the navigational knowledge by using English". The study of navigational knowledge can take the following forms:

(1) Self study. On account of the shortage of study channels, self study is still the main form of navigation knowledge learning. English teachers can cooperate with the navigation teachers systematically and planned learning of all the navigational knowledge including IMO conventions and regulations;

(2) Attending classes. English teachers can regularly follow the students in completing the processes of preview, study, revision, assignments and assessment;

(3) Taking examinations. Beijing New Oriental School teachers will take up the TOEFL, IELTS and GRE examinations for the first hand experiences. Maritime English teachers should join their students in taking up the certification examinations, not only for the learning of navigational knowledge and examination contents, but also going through the painful experience and increasing their perceptual knowledge to make their teaching more targeted and emotional;

(4) Attending lectures. Maritime English teachers should participate in the navigational lecture activities and even prepare lectures on relevant topics of their own in that both forms are processes for improvement. On the coming into force of the Amendments to STCW Convention, most participants in discussions and seminars are navigational teachers, with little involvement of English teachers. As a result, they know little of the requirements and spirit of the new international conventions;

(5) Attending conferences. Maritime English teachers seldom have the opportunity to attend academic conferences and at the same time, they believe the navigational conferences are not related to them. Actually, the contents of many maritime conferences closely concern maritime English teaching, such as, maritime simulation conference and pollution prevention conferences, etc.;

(6) Discussions. Seminars are a good channel for acquiring information, in which participants appear in equal status and conduct discussions on topics of 
interest and draw conclusions, with new ideas and innovations often inadvertently, which is of great help to the thinking of maritime English teachers;

(7) Lesson planning. The preparation for maritime English teaching should take the form of collectivism in determining the contents, key points and difficulties, teaching progress and speed, breadth and depth, coaching and testing simulation via drawing upon useful opinions. In fact, collective lesson planning is also an important process for teacher refreshing;

(8) Getting onboard ships. In accordance with the "10th Decree, Ministry of Transport," maritime English teachers should have onboard service experience and even hold seafaring ranks. Reasonable arrangement for English teachers to get onboard for practice gives good opportunity for acquiring professional experience;

(9) Certification. Some maritime higher institutions have tried to send English teachers to learn the navigational knowledge and acquire certificates after examination before engaging in maritime English teaching. This is a good practice and is the initial stage for criterion of maritime English teaching.

There are various means for English teachers to learn and study navigational knowledge and the key lies in the support from the college authorities and the demand of the teachers.

\section{Conclusions}

It is admitted that maritime English teachers are engaged in a different career, which puts up higher demand for the teachers' self management. As long as teachers' self management is closely tied to the sustainable development of the institution and comes out of the teachers' need and pursuit, it will benefit the improvement of the teaching effect and professional development of the teachers.

\section{Acknowledgements}

This paper is funded by the research project of "Training of Seafarers Sailing in Polar Waters," Shandong Province, China, Project number, J 16WG 47, and the "2015 Scientific Research Project", No: 2015-R-007, Qingdao Ocean Shipping Mariners College.

\section{References}

[1] Lu, Y.-J. 2010. "Five Principles of Classroom Management." Experience Online.

[2] Chen, J.-L. 2000. Organization and Management of Modern English Teaching. Shanghai: Shanghai Foreign Language Education Press.

[3] Zhou, Y. 2005. "Investigation and Studies on the Need of English Teacher Development." Foreign Language Teaching and Research.

[4] Jarvis, J. 1992. "Using Diary for Teacher Reflection on In-service Course.” ELT Journal.

[5] Bastidas, A. J. A. 1996. "The Teaching Portfolio: Tool to Become a Reflective Teacher.” English Teaching Forum.

[6] Underhill, A. 1992. "The Role of Groups in Developing Teacher Self-awareness.” ELT Journal.

[7] Barnard, R. C. G. 1995. "Distance In-service Training for Language Teachers: A Suggested Approach.” English Teaching Forum.

[8] Li, A.-M. 1998. "Studies on the Planning for Classroom Teaching." Journal of Yancheng Teachers' College.

[9] Richards, J. C., and Charles, L. 1994. Reflective Teaching in Second Language Classrooms. Cambridge University Press.

[10] Bartlett, L. 2000. Teacher Development through Reflective Teaching. Foreign Language Education and Research Press.

[11] Zhao, S.-M. 2009. "Teaching Diary, an Effective Channel for Reflective Teaching." Science of College English Teaching.

[12] Blookfield. 2002. ABC for Critic Reflection. China Light Industry Press.

[13] Dai, W.-D., and Ren, Q.-M. 2006. Foreign Language Teaching and Teacher Development, Theory and Practice. Shanghai Foreign Language Education Press. 